Explanations for death by suicide in northern Britain during the long eighteenth century

\author{
R. A. Houston
}

\begin{abstract}
This article uses coroners' inquest findings, media such as newspapers, magazines, pamphlets and broadsides, and family correspondence (all drawn from Scotland and the north of England) as well as civil and criminal court records and medical and legal writings from both countries to explore perceptions of the link between state of mind and self-inflicted death. It asks how doctors, lawyers, families and 'society' at large conceptualized, responded to and coped with suicide, questioning the extent to which it became medicalized: i.e. consistently linked with mental pathology. The aim is to square the apparently clear-cut, but very different understandings of doctors and lawyers on the one hand and coroners' inquests on the other with the more emotionally charged and morally complex ways those both close to and distant from attempted or successful suicides related to their situation.
\end{abstract}

Keywords: suicide, insanity, medicalization, medicine, media, newspapers, doctors, lawyers, religion 
Historians have little explored how past societies understood the deaths of the insane. Yet, as Smith shows in the introduction to his article, early-nineteenth-century English patients could as easily leave a lunatic asylum on a bier as on their feet. Even good recent literature on madness regards mortality as an end to observation and treatment, perhaps a failure of management or therapy in practitioner and asylums terms, or a conclusion of experience, treatment or incarceration in a patient-centred approach (Wright, 1997; Michael, 2003a: 91-2, 110; Berkenkotter, 2008; Coleborne, 2010: 97-8, 134-6). Suicide is an exception to this picture for two reasons. First, it initiated a process by which survivors came to explain a death that was particularly, perhaps uniquely difficult to comprehend (Bailey, 1998). Second, because of the modern (and modernised) perspective that few would kill themselves who were not to some degree mentally troubled. The dominant model in recent historiography comes from Michael MacDonald's articles on English suicide and his subsequent book with Terence Murphy, which argued that a near-automatic link between voluntary death and mental disorder became established during the long eighteenth century (MacDonald, 1977; 1986; MacDonald, Murphy, 1990). This line came out of a focus on English coroners' inquest verdicts, which began increasingly after the Restoration to find suicides non compos mentis (insane and thus blameless) rather than felo de se (culpable criminals). MacDonald and Murphy argue that, by the mid-eighteenth century, inquests found most suicides lunatic, a 'selectively medical' understanding that eventually became broadly accepted by lay and professional observers alike. Generalised and sometimes passionate religious opposition to suicide was also softened into toleration by a secularizing, civilizing or Enlightening process. As an all-encompassing and apparently well-substantiated interpretation, this modernisation narrative has reached the status of orthodoxy. Among others, Jeffrey Watt introduced his edited volume on European suicide by rehearsing that it became 'decriminalized, secularized, and medicalized' during the early modern period (Watt, 2004: 8; Healey, 2006). Some of the contributions to Watt's volume show this picture to be over-simplified and indeed there is a nagging 
sense of dissatisfaction with it shown in some more recent literature (Wright, Weaver, 2008; Siena, 2008: 59-60, 63-4).

This article argues that the medical link between insanity and suicide was a selective and contingent one, embedded in religious, social, and moral assumptions, that vitiates simple models of change. In understanding how insanity and its implications for death were negotiated in practice, the most helpful recent development has been Akihito Suzuki's encapsulation of what we know of relations between families and medical practitioners in the phrase 'domestic psychiatry' (Suzuki, 2006: 63-4; Houston, 2003b). Deep into the nineteenth century English psychiatric practitioners were caught between their working environment and their training and experience: between 'endorsing the old family-dependent diagnostic pattern and ... insisting that the diagnosis was a scientific one' (Suzuki, 2006: 69, 183).

Rather than seeking to offer an aetiological or epidemiological survey of madness and suicide, this article assesses medical, legal, familial and media commentary on the relationship between suicide and madness in Britain. It examines first how relationships between mental afflictions and death by suicide were understood and communicated by British doctors to families and coroners' inquests and how medical publications mediated the connection. Medical professionals explicated and contextualised the deaths of their clients or subjects, delineated the relationship between madness and death, and advised and counselled families on the deaths of their mentally ill members. Some insights are given into the emotionally charged yet complex ways those close to attempted or successful suicides related to their situation. The second section sets out how the law treated insanity and responsibility in instances of attempted or completed suicide outside the coroner's inquest. It emphasises the rigorous procedures in all sorts of tribunals, under both Scottish and English law, compared with the inchoate standards applied by English inquests. The third section explores how suicidal deaths were portrayed in newspapers and pamphlets, for they were an important interface between medical and legal interpretations of suicide and madness on the one hand and broader societal constructions on the other. The 
geographical focus is on Scotland and the north of England: what might be called northern Britain.

Dealing with understandings of the relationship between madness and suicide, the article uses coroners' inquest findings, printed media, and family correspondence as well as medical and legal writings to explore perceptions of the links between state of mind and suicide. Concentrating on coroners' inquests alone can distort the way we see the connection because they present only one view: their beguiling insights into a lost mental world belie sometimes intractable problems of interpretation. The argument is that there was no medicalization of suicide in the sense that lay or professional observers came to see it normally as the result of madness; properly medical understandings were as discriminating as were legal ones (Houston, 2008). Media constructions that appear to offer a generalised exculpatory association between madness and suicide were in reality complex moral judgements about social worth. The article touches on asylums, but its main focus is on deaths in domestic locations. Asylums are a problematic place to start looking at madness and suicide because: only something like a fifth or a sixth of admissions to late-eighteenth- and nineteenthcentury British asylums had a history of suicidal attempts or inclinations; concerns with cure and public image meant close supervisory regimes and therefore very few suicides among the institutionalised (Digby, 1985: 198; Shepherd, Wright, 2002: 191-3; Michael, 2003b: 52-7; York, 2009). ${ }^{1}$ Thus the article is one sign of how, in Melling and Forsythe's words, "historians of the asylum have moved the area of debate from the discourse of psychiatrists and their institutional practices to the wider social and demographic environment in which the asylum flourished' (Melling, Forsyth, 2006: 97).

\section{Medicine, madness and suicide}

In the century after the Restoration English coroners' inquests came increasingly to find those who killed themselves non compos mentis; the normal verdict in earlier centuries had been felo de se, meaning that corporal and patrimonial penalties might be 
visited on those guilty of self-murder (Houston, 2010). The latter verdict assigned responsibility, the former absolved - and did so in terms that look psychological. This change might be seen as initiating a routine link between madness and suicide. Juries adopted the fiction of near-universal lunacy to protect the reputation and property of the dead and doctors were obliged to change their line as a result. Of inquest findings on suicide, Jeremy Bentham wrote: 'perjury is the penance that, at the expense of religion, prevents an outrage on humanity' (1838, vol. 1: 480). In fact contemporaries recognised the verdict for the oddity it was, flying in the face of most accepted canons of proof. For their part medical men who argued that the verdict of felo de se was unjustifiable 'owing to insanity being present in every instance' used the opinion strategically to comment on more than suicide or tactically (and obliquely and selectively) to tell their clients what they wanted to hear (Winslow, 1840: 337).

The last quotation comes from Forbes Winslow, writing in 1840 because, as he states in his book's preface, a paper he gave to the Westminster Medical Society provoked 'animated discussion' (Winslow, 1840: v). The reason for this is that most doctors flatly disagreed with Winslow, whose main driving force was a mix of religious fervour and social awareness, over his contentious - some thought ridiculous - medical ideas (Anderson, 1987: 275n). This carried on a tradition that had its roots in religious dissent rather than in the sort of Toryism Winslow touted. Earlier examples included Sir Richard Blackmore's staunch refutation of the alleged connection between 'enthusiastic' religion and madness in the early part of the eighteenth century and the late-eighteenth-century attempt by Thomas Percival to develop ideas of 'temporary distraction' in cases of suicide (Haakonssen, 1997: 162-3). Indeed, from Elizabethan Timothy Bright and Jacobean Robert Burton onwards, it was 'the warmer sort of Protestants' who were most active in singling out a role for medical interpretations of the link between suicide and madness as they sought to isolate legitimate demonstrations of religious faith from manifestations of mental dysfunction (Anon., 1750: 61-4). Here religion stood alongside a medical interpretation and put that understanding in its service rather than being replaced by it. 
Other nineteenth-century physicians who ventured to suggest a more general connection usually had a specific agenda. J. G. Davey M.D. argued in August 1870 'that the act of suicide is at all times and under every kind and variety of circumstance the effect of a pre-existing cerebro-mental disease'. Thus, he trumpeted, 'I claim for the "self-murderer" his abolition or freedom from all and every responsibility; and, as a sequence, the non-liability of his heirs or representatives to suffer either in person or in purse in any way whatsoever'. Davey was primarily exercised by the attitude of life insurance companies, but he was tilting at windmills (Davey, 1870-1: 410). 'Insanity' was only a recognised cause of death in three out of 975 deaths resulting in claims to the Scottish Widow's Fund in the years 1853-9 and three from 1,398 deaths 1860-66; there had been none at all 1846-52. 'Suicide', a recognised cause of death and by this date generally an acceptable one for payment to be made, comprised six, thirteen and six in the respective periods (Begbie, 1867-8: 969-70, 980; Winslow, 1840: 132-3).

Medical practitioners seldom followed this line and were more likely to look for a connection with physical pathology rather than psychogenic anomalies when explaining suicide. In the eighteenth and early nineteenth century medical and other observers tried their best to link the acceptable lunacy of suicide to physical ailments rather than allowing the taint associated with mental illnesses, acting as employees who legitimised conventional lay understandings rather than introducing new professional ones. One way was to focus on a physical ailment like a fever or inflammation that had psychotropic effects, an important emphasis on the pyretic, where insanity was commonly viewed as a-pyretic by contemporary practitioners. When Miss Allan's brother took an overdose of laudanum in May 1824, a Durham doctor opined that, during a drinking bout the night before, bad wine had 'caused a stupor or inflammation of the brain' and thus created a temporary insanity (Durham University Archives, Wharton 754). This diagnosis, which had the authority of tradition in resembling part of Robert Burton's early-seventeenth-century analysis of the physiology of melancholy, provided a medical gloss that served the needs of the family (Gowland, 2006: 81). 
The reasons why medical men offered these sorts of explanations are not far to seek. Serious issues could arise from accepting that a person had died in a state of insanity, ranging from the validity of any contracts or will they might have made to the more generalized stigma of madness and the effects it could have on the reputation and even marriageability of other members of a family not directly tainted by the label (Bonfield, 1997; Houston, 2003a). As Boulton and Black show, of the reporting of lunacy as a cause of death by lay searchers in seventeenth and eighteenth century London, any link between insanity and self-murder was often suppressed except for the poor or poorly connected. Similarly, friendless paupers had, since at least the sixteenth century, been the most likely group to end up as anatomical subjects for British dissections (Houston, 2010: 248-50). The better-off were a very different proposition and the Durham doctor would have sympathised with George Cheyne, who observed a century before that 'nervous distempers especially, are under some kind of disgrace and imputation, in the opinion of the vulgar and unlearned; they pass among the multitude, for a lower degree of lunacy, and the first step towards a distemper' $d$ brain: and the best construction is whim, ill-humour, peevishness or particularity; and in the sex, daintiness, fantasticalness or coquetry' (Cheyne, 1733: 260).

A similar exculpatory narrative was constructed around a northern clergyman. In November 1834 Rev. Henry Ridley shot himself in the mouth while out hunting with his friend Dr Hey (possibly of the York Retreat). In letters to Sir Matthew Ridley about the suicide, Hey wrote of 'mental depression'. The vicar's wife had persuaded her husband to see Hey, but Ridley told Hey 'he was satisfied that I could be of no benefit to him as his malady was on the mind. In fact, said he, my heart is broke and I feel that nothing can be of any avail.' Hinting at some sexual disease or dysfunction, Hey recounted one possible, if trivial, reason for the depression: Ridley told him 'what the cause of it was, binding me to the strictest secrecy especially from Mrs and Miss Ridley. It turned out to be so ridiculous that I endeavoured by every possible argument to show it to him in that light tho' without success'. Ridley became agitated then 'very low, saying that even his household now despised him; that he was an outcast from society'. For all the 
psychological help he tried to give Ridley, Hey concluded by attributing the onset of the depression to 'a bilious attack before which time his mind had not been affected'. Hey sought to balance the possible, the secret, the trivial and the physical as counterweights to any assumption of psychogenic madness (Northumberland Record Office, ZRI/30/14). Like other medical men torn between a need to be diplomatic and a concern to be accurate, Hey focused on somatic illness as a reason for suicide. Meanwhile the women in the family blamed a servant who allowed Ridley to leave his sight, a choice of scapegoat based on emotion and perhaps social prejudice that ignored years of melancholy and earlier examples of Ridley's single-minded determination to die.

The distinctively medical contribution to Georgian coroners' inquests was opening the body, not unravelling the mind. The medical men called to Cockermouth in September 1802 to sew up the self-inflicted cut in Peter Richardson's throat made no comment on his mental state, leaving it up to a servant girl to explain to the inquest after he died that her master showed no 'want of understanding' when sober even if he could be 'harty and pasionate' in drink, suggesting only that he was 'broken hearted ... afraid he would come to want' and adding that he regretted what he had done and asked her to pray with him - a sign of reason, remorse and repentance (Cumbria Record Office Whitehaven, D/LEC/CRI/111/9). This was lay rather than professional psychologising. A century earlier the physician called to attend to John Atkinson after he had cut his throat threw only incidental light on his state of mind when he mentioned how the dying man had admitted going to a well in Wigton (Cumb.), but 'dreadinge some might see him' returned home to cut his throat in private: again an action requiring the use of reason (Cumbria Record Office Whitehaven, D/LEC/CRI/5/3). Atkinson might have been morally insane, but his reason had not left him.

The only time a Cumbrian surgeon did pronounce at any length on mental state to an inquest was in the case of octogenarian John Braithwaite a few days before his death late in 1803. John Jackson of Egremont visited him before his death and found him 'complaining of an uneasiness and confusion in his head and giddiness and want of recollection', which he diagnosed as 'an affection of the brain'. He found the old man 'in 
a very desponding way wholly from want of his mental faculties ... deranged and deprived of his true reason and understanding and rendered incapable of forming a true judgement of what he did' (Cumbria Record Office Whitehaven, D/LEC/CRI/112/13). Practitioners summoned by English coroners 'were selected not for their special skill in reading dead bodies as generic texts, but for their supposed capacity to provide evidence in relation to the specific circumstances of a specific death' (Burney, 1999: 109; Rudolf, 2008). Medical men rarely appeared as witnesses before northern English coroners' inquests and, when they did, talked about physiological aspects of wounds and ingestions rather than psychological dimensions of their patients. Inquests sat on the view of a body and the evidence that interested them was principally what lay before them; witnesses of any kind simply helped the jury to see more clearly.

\section{$\underline{\text { Law, madness and suicide }}$}

A judicious approach to the apparent connection between suicide and insanity among doctors paralleled a discriminating judicial treatment by lawyers. In every court except a coroner's the standards of proof of mental disability were as stringent as they were clear. Scots law was particularly rigorous about evidence and one of two famous cases from the early nineteenth century was appealed to Scotland's supreme court and then to the House of Lords, which confirmed the Court of Session's judgement in May 1813, allowing the case to enter the 'English Reports' as British case law (M'Adam [sic] v Walker, 1 Dow P. C. 148). Explaining the law to medical students, Professor Robert Christison summarised the more famous case in his Edinburgh university lectures on medical jurisprudence c.1830: 'A person in the better sphere of life, in order to legitimise his children by a woman of low rank, is legally married to her; but, resolving never to confront his old companions after his depradation, commits suicide immediately after the marriage has been celebrated' (Edinburgh University Library Special Collections, Dk4.57, 'Of Disqualifications', 8 [insert]). Those who sought to prove Quintin Macadam of Craigengillan insane summarised what they took to be signs of his mental state, as perceived by those with whom he had day to day intercourse. 
'Occasionally he had very low spirits and repining gloomy fits. At other times he was very elevated. When the disease was on him he was violent and outrageous to the last degree. ... he often spoke of destroying himself ... His eye had a particular appearance which is only remarked in people who are insane. His mind was filled with jealousies and suspicions, which is one of the most common and decisive symptoms of insanity. He was subject to vain and groundless imaginations, \& believed that he was despised by every body.' He did not like being looked at (National Archives of Scotland, CC8/5/29/1, Walker v Macadam: 280).

In the other (earlier) case, Callman v Gourlay, counsel pleaded that, though their client's brother had hanged himself, this was only a temporary fit rather than a sign of chronic insanity.

Altho the coroner's jury in England are in the practice of adopting a very useful fiction of law, and uniformly imputing suicide to insanity, and altho such depression of spirits as produces suicide may be construed into a momentary insanity, yet ... [it is not] that permanent insanity or imbecility which ought to hinder a man from having management of his own affairs ... Altho when depression of spirits arrives at the height of suicide, it may perhaps be construed into insanity, yet the respondents do not understand that this depression in its progress, unless it rendered a man completely unfit to manage his affairs, was ever held sufficient to convict a man of lunacy (National Archives of Scotland, CC8/5/22, Callman v Gourlay [np]).

Not all types of mental problems removed intention and therefore responsibility, and contemporaries perceived gradations of symptoms, and therefore effects on the exercise of will, even within syndromes. By 1830 Christison could generalise further. 'There is hardly any single extravagant act or expression, that will prove a man to be insane: it can only be proved by comparing together many similar acts or expressions' (Edinburgh University Library Special Collections, Dk.4.57, 'Of Disqualifications': 19). Failures of judgement 'must be manifested in several actions, if not habitually' (Edinburgh University Library Special Collections, Dk.4.57, ‘Of Disqualifications': 6). Of 
itself, a single act such as committing suicide was not proof of mental derangement. As will become clear later in the article, insanity defences too required a prominent and more-or-less consistent suite of words and deeds to be successful.

The advocate (like an English barrister) in Callman v Gourlay was plainly relieved that Scotland did not have 'crowner law', though he also recognised the inconvenience to his arguments caused by having its operation as a backdrop to his case. Scots law was very different from English, but both in their writings and in court, English lawyers were as likely to oppose the link between suicide and insanity that was becoming routine for coroners' inquests, even when they too were forced to recognise its currency. Earlyeighteenth-century English legal writer, William Nelson, summarised the practical implications in a non-committal way.

It has been the Opinion of Learned Men, That a Person who is Compos Mentis cannot be guilty of so much Malice towards his Person, which may occasion him wilfully to kill himself; because naturally the Intentions of Men aim at what is good for themselves, and at what conduceth to their own Preservation: and therefore 'tis to be presumed, that where a Man killeth himself, he is not Compos Mentis (Nelson, 1710: 258).

This guarded exposition conceals a deep-seated reservation about what inquests were starting to do when Nelson wrote, bringing in verdicts which treated suicide as conclusive evidence of mental unsoundness. By doing so, writers like Nelson argued, the juries were hardly being candid, but were instead simply evading the artificial doctrine of constructive murder because of the material and religious loss that a suicide incurred. In The pleas of the crown Nelson's contemporary and sergeant-at-law, William Hawkins, took notice of

a strange Notion, which has unaccountably prevailed of late, That every one who kills himself must be Non compos of Course; for it is said to be impossible, That a man in his Senses should do a Thing so contrary to Nature and all Sense and Reason. ... May it not with as much Reason be argued, That the Murder of a 
Child or of a Parent is against Nature and Reason, and consequently that no Man in his Senses can commit it? (Hawkins, 1716: 67; Moore, 1790, vol. 1: 32241).

In the 1760 s the famous legal writer and judge, William Blackstone, rehearsed earlier arguments almost verbatim, concluding: 'The law very rationally judges, that every melancholy or hypochondriac fit does not deprive a man of the capacity of discerning right from wrong; which is necessary ... to form a legal excuse. And therefore, if a real lunatic kills himself in a lucid interval, he is a felo de se as much as another man' (Blackstone, 1769: 189-90). Half a century on, English lawyers were still universal in their condemnation of such an assumption. In a section dealing with suicide, which is as short as those of most legal texts, G. D. Collinson acknowledged in 1812: 'As a non compos cannot commit murder, so neither can he be felo de se' (Collinson, 1812: 494). He continued, explaining in a footnote that juries confused 'strong passions' with insaity:

c. 26 . The notion is prevalent, that whoever commits suicide is under the influence of insanity; it being supposed impossible for a person in his senses to do an act so repugnant to reason and nature.

c. 27. This, however, is bad law.

c. 28. And wretched philosophy.

Georgian clerics assimilated these arguments into their discourses on social and moral matters. Writing as a High Anglican clergyman and academic, Charles Moore warned in 1790 of the indiscriminate association between madness and suicide: 'But some, who are ever desirous of leaning towards the side of humanity, are inclined to judge, that every act of suicide (being so horrid and unnatural) implies a subversion of the brain, or a species of madness' (Moore, 1790: 4) Such arguments were frequently rehearsed, not only by the clergy (the villains of MacDonald and Murphy's account) but by most learned people. When the Earl of Egremont, lord of the honour of Cockermouth and Egremont, condemned 'verdicts of lunacy when suicide is a rational decision', he spoke as an educated man as much as he did a financially interested franchisee with the 
right to the forfeited goods of culpable suicides (East Sussex Record Office, SAS/A748). Indeed, writers from every background continued throughout the long eighteenth century to question the association made by coroners' juries (Andrew, 1988). They argued for a discriminating approach to the connection between insanity and suicide as is indeed evident in every domain other than post-Restoration coroners' inquests.

Scots (and some English) observers who wrote about English coroners' juries suggested that they could offer verdicts of non compos mentis because to do so made no difference to anything except the dead person's reputation - vital as this was to economic and social life. This made it simple for them to exalt 'compassion over truth and justice' and offer a verdict, 'which excluding all offence effectually screens from all reproach' (Moore, 1790: 324). Coroners' inquests were the odd man out when it came to understanding the link between madness and suicide. Inquests may have felt sympathy for the families of suicides, yet criminal court juries comprised of the same kinds of middle-rank people could make discriminating decisions about insanity and responsibility, which had similar consequences for the reputation, emotional equanimity, and material circumstances of the accused person's family - not to mention his own peace of mind and chances of life. In other contexts English (and Scottish) courts showed an ability to decide on someone's mental fitness for trial, their responsibility for a crime, or their ability to manage their business affairs, based on a close and discriminating understanding of lunacy and its various (and variable) effects on voluntary action (Houston, 2000; Adamson, 2004). Even lay searchers of the dead in eighteenth-century London could make the distinction and Dr William Black noted: 'The coroner's inquest generally returns suicides as lunaticks, after reciting the mode of their death; but the searcher's reports in the bills of mortality, have invariably ranged lunatic and self-murder under two distinct heads' (Black, 1789: 128. Siena, 2010). Except in the coroners' courts, decisions over personal agency could indeed follow 'truth and justice'.

\section{Public opinion, madness and suicide}


Historians of psychiatry tend to concentrate on how medical understandings are constructed among doctors: if they go beyond this it is to explore how medical knowledge and opinion were mediated to courts or perhaps to patients and their families or parishes. The first half of this article has focused on these professional presentations and other contexts have been covered, most notably criminal courts (Eigen 1995). There are, however, other fora for representations of the link between madness and suicide that probably had a much wider constituency. Thus, for example: literary scholar Barbara Gates has examined factual and fictional representations of suicide during the Victorian period (1988); Donna Andrew has looked at how the death of Sir Samuel Romilly appeared in the press (2004); MacDonald and Murphy have sampled southern English newspapers to assess how understandings were created in the new 'public sphere' of the eighteenth century (1990: 301-37); and an exciting new article by Jeremy Caradonna opens up French newspapers to scrutiny (2010). For both Scotland and England, newspaper reports allow understandings of madness and suicide to be analysed at two levels. The first is the use of terms like 'lunatic', 'melancholy' or 'disordered' to describe a person's state of mind when they attempted or succeeded in making away with themselves. The second is in the social selectivity of reporting. In short, newspapers presented an image of suicide as a matter for the dependent classes and of the mental state of those they reported as one of moral failure rather than medical pathology. Newspapers did help to medicalize understandings of suicide, but by stressing the need for prompt professional doctoring rather than by opening up the mind of self-harmers or self-murderers.

The tone of reporting is set by a short intervention in a Whitehaven-based newspaper, the Cumberland Pacquet, commenting on the conventional vocabulary of reporting deaths in 1805 (Cumberland Pacquet, no. 1588: 19 March 1805).

It is curious to remark a striking diversity in the modes of expression currently used to denote the death of different descriptions of persons. They whose names make up the ordinary bills of mortality, are said to have died, or paid the debt of nature. The capital convict is always launched into eternity. The suicide 
as constantly puts an end to his existence. These expressions are by no means of equal import.

The Pacquet's point was that it was wrong to suggest an end with suicide because those who took their own lives were surely damned; much of its reporting was overtly hostile to suicide and contemporaries were aware of the differences between representations of agencies and eschatologies. The value of the story is to highlight that death has a context made up of precedent and antecedent interpretations, of which the fate of the soul is just one.

Some reference to mental state is made in 84 of 214 reports of attempted or successful suicide (39\%) drawn from a sample of Scottish newspapers, 1748-1826. That they offered any explanation of the event is at one level surprising, because such an attribution was not a routine part of the investigation of suspicious death in Scotland, which dealt with agency rather than responsibility, and because it had, to all intents and purposes, no legal effect after forfeiture for civil debt was abolished there in 1748. Saying that a person died disordered in their senses might be seen as a defence of their reputation, but its purpose was simply to confirm that the case was closed. Furthermore Scottish investigations of sudden death were conducted in private by magistrates who took evidence at discretion rather than in the open forum of a coroner's inquest with its lay jury, making Scottish newspaper commentary a gloss rather than a report.

\begin{tabular}{|c|c|c|}
\hline mental state & $\mathbf{N}$ & $\%$ \\
\hline disordered/deranged & 25 & 30 \\
\hline melancholy & 14 & 17 \\
\hline $\begin{array}{l}\text { depressed/despondent/discontent } \\
\text { ed }\end{array}$ & 14 & 17 \\
\hline insane & 13 & 15 \\
\hline
\end{tabular}




\begin{tabular}{|l|c|c|}
\hline delirious & 12 & 14 \\
\hline other & 6 & 7 \\
\hline total & 84 & 100 \\
\hline
\end{tabular}

Table: vocabulary describing mental state of attempted and successful suicides in Scottish newspapers, $1748-1826^{3}$

One might hypothesise that this style of reporting subliminally changed perceptions of madness and suicide. However, some of the longer reports make it plain that suffering from mental problems did not exonerate the dead. The Aberdeen Journal reported in 1761 the case of an Aberdeenshire woman, who, 'for some time disordered in her senses', had tried to hang herself. The account added that neighbours had prevented 'her wicked purpose'. 'Yet so strong is her distemper of mind, that instead of being thankful for her preservation, she expressed great dissatisfaction on recovering from her swoon' (no. 647: 2 June 1760). Derangement could be blameworthy. Indeed, the connection between mental problems and suicide in the newspapers did not always flow in one direction. An Aberdeen woman hanged herself from a tree, but her husband cut her down and saved her life. 'She is, however, disordered in her sense [sic] ever since' (Aberdeen Journal, no. 1162: 16 April 1770). For others the attempt was said to have helped a state of mind, carrying on the emphasis in Calvinist conversion narratives about the redemptive power of contemplating death. A Montrose woman threw herself out of a high window 'in a fit of delirium', but 'far from being injured by the fall, it is said that her mental health has been in some measure restored' (Aberdeen Journal, no. 4052: 7 September 1825).

The phrase 'fit of delirium' can be described as a medical judgement, but medicine did not own other terms like 'discontent' or 'melancholy': the latter word could also mean sad or lamentable and could be applied to condemn the suicide itself rather than the state of mind causing it. An account from Forfarshire turned an 
apparently neutral or even sympathetic term like 'melancholy' into a moral judgement. It told how 'a man upwards of sixty years, and in his third marriage, hanged himself. It is melancholy to observe the rapid progress which the detestable crime of suicide is making in this country' (Aberdeen Journal, no. 1266: 14 March 1774). This case also exemplifies the ambivalence of much reporting: suicide was saddening, but it was also wrong. In April 1799 'a woman of Milton near Kirkintilloch put a period to her existence ... She had been long in a deranged state, and had arisen during the night unobserved by her husband, and committed the desperate act' (The Edinburgh Weekly Journal, 2(67): 118). Desperate here was a religious term that meant 'without hope' rather than simply 'at the end of her tether' and, even when mentioning derangement, the judgement of her act was elided by the mention of secrecy - which still had undertones of the ulterior and which the newspaper implied required thought and calculation.

Newspaper reporting of the mental state of English suicide is more closely tied to the wording of coroners' inquests, which were public and participative events into which men of the middling sort brought their own ideas of evidence and proof, and from which they took not only their findings, but also ideas acquired through deliberations and direction by the coroner. Some 163 out of 235 cases reported by the Newcastle Courant gave an attribution of mental state (69\%): five were felo de se and the most common label was 'lunacy' or 'insane', expressed in italics at the end of the entry to indicate a verdict (four-fifths of cases), followed in descending order of frequency by 'deranged', 'disordered' and 'melancholy'. For the Cumberland Pacquet the statistics are 147 of 236 (62\%), of which 18 are felo de se. In the remainder, lunacy or insanity predominate as in the Courant. English newspapers seldom provide any more information than what they could derive from inquest verdicts. Prior to the $1790 \mathrm{~s}$ any description of mental state was unusual and it is worth noting that only then did newspapers start giving verdicts routinely - long after coroners' inquests had come to offer 'non compos mentis' as their usual verdict on suicides.

When they mentioned medical intervention, newspapers in both countries confirmed that the role of surgeons and physicians was to pronounce on the physical 
appearance of the corpse and the proximate cause of death, rather than the ultimate mental state that brought it about. For example, the Cumberland Pacquet reported how Mr Theophilus Smith, confined in Stafford gaol for shooting a Mr Wainright of Liverpool, tried to do the same to his wife while she was visiting and then shot himself in the head: 'the ball entered a little above the left ear, passed through his head, came out on the opposite side, and caused his immediate death' (no. 1370: 13 January 1801). Nothing explicit was said of Smith's mind. English newspapers proffered a positive model of medical intervention that sought explicitly to change attitudes that might be antithetical to effective intercession. Referring to the suicide by hanging of an apprentice in 1738, the Newcastle Courant was at pains to correct 'an ignorant opinion that prevails with some people, that no one must meddle with a person in such circumstances' (no. 680: 6 May 1738). A generation later it told of a servant maid found hanging in a cellar at Painterheugh. Two hours after 'this unhappy wretch' was cut down, a considerable amount of warmth remained in her clothes and unsuccessful efforts were made to revive her, but (the paper announced) 'if proper assistance had been given on the immediate discovery of the body' she might have recovered (no. 5281: 13 December 1777).

Newspapers created expectations of physical treatment for those who might be saved from their own self-harm. When it came to mental state their reporting described people whose spiritual salvation was doubtful, whose minds were clear and rational, and whose purpose was wrongful. Reporting that focused on a link between madness and suicide was socially selective and the implication was that only a certain class of self-murderer was mad. Yet here again 'lunacy' was not exculpatory, but accusatory. The better sort who killed themselves were either not reported at all or their death was 'laundered' by placing them among the naturally or accidentally dead in the column of local deaths rather than local news. The protection of rank was extended to sensational instances of self-harm short of suicide. A postscript to a letter of 21 June 1753 from Thomas Cockburn at Edinburgh to Sir John Hall of Dunglass describes an horrific event in Northumberland: Lord Charles Gordon 'cut up his yard [penis] and then cutt off an inch 
or two, by which he was in hazard of bleeding to death. His wounds were dressed up but his life despaired of. He has been in a rambling mad condition these several weeks' (National Archives of Scotland, GD206/2/261/9). Newspaper reports were anonymised and sanitised of the detailed fact, the intent and the madness. The Edinburgh Evening Courant offered the following account. 'Last week a person of high distinction stabbed himself at Wooler in Northumberland in a very cruel manner; but we hear, by being discovered, and proper assistance, his life is in no great danger' (Edinburgh Evening Courant, no. 5842: 26 June 1753). In contrast, the Newcastle Courant, read by the gentry and bourgeoisie of the north-east, did not report this case.

At the other end of the spectrum of status and respectability, insanity might be rejected for quite different reasons. For accused or convicted criminals, desire for death or even an attempt to die were not necessary signs of an underlying insanity that precluded responsibility. Like flight they were, instead, more commonly taken as indicators of guilt. A newspaper report from 1725 was explicit. 'Yesterday was execute in the Grass-market [of Edinburgh] Archibald Waker, weaver in Luss [Dumbartonshire], for the Murther of Walter M'Farline, who, to the last Moment, denied his being guilty of the Murder; but his Behaviour in Jayl, and his attempting to dispatch himself the Morning before his Execution, makes his Speech by far the less credible' (Edinburgh Evening Courant, no. 981: 18 March 1725). Broadsides that reported criminal trials affirmed the same message about the lack of connection between suicide and madness. When John Stewart was on trial for his life at Perth in 1833 for the murder of his wife, a number of witnesses gave evidence to prove that he "had formerly attempted to commit suicide, - that he was subject to epiliptic [sic] fits, - and that he was insane'. However, others said the exact opposite, including Dr Ma'colm, physician in Perth and also physician to Murray's Royal Asylum there, who 'thought him perfectly sane when he first saw him, anid [sic] is of the same opinion still; does not hold an attempt to commit suicide an infallible proof of insanity' (Anon., 1833). This was the opinion that prevailed and Stewart was sentenced to death. 
English media treated attempted or successful suicide of criminals in the same way as Scots. Eugene Aram, a Knaresborough schoolmaster, was condemned to hang at York on 6 August 1759 for a murder committed in 1745. The night before he was due to be executed he slashed his arms and was nearly dead from loss of blood when found in the morning. 'By proper applications he was brought to himself and, though weak', was taken to his execution on schedule and subsequently gibbeted (Anon., 1759: 23). A pamphlet published to cash in on the execution reproduced a suicide note allegedly left in his cell.

To die is natural and necessary ... I fear no more to die than to be born. But the manner of it ... should be decent and manly ... Certainly no body has a better right to dispose of a man's life than himself ... As to any indignities offered to my body, or silly reflections on my faith and morals, they are, as they always were, things indifferent to me. I think, though contrary to the common way of thinking, I wrong no man by this, and hope it is not offensive to that Eternal Being that formed me and the world ... (23-4).

Inviting its readers to deplore Aram's impiety, the pamphlet just as coolly closed by distancing itself from his deism. 'Notwithstanding he pleads a sovereign right over himself, in vindication of this last horrid crime, and appears, at first view, actuated by honour and courage, yet a little reflection will convince any one, his motive for such an inhuman deed was nothing more than the fear of shame' (24).

\section{Conclusion}

Printed media sensationalised, censured, and even satirised suicide. They not only registered and disseminated an interpretation, but also shaped understandings through use of language and selective reporting (Zelnik, 1988: 57; Snell, 2005). Newspapers created the impression that suicide came not out of mental pathology, but from a reasoned if wrong choice about how to deal with normal extremes of emotion and circumstance. Any pathology was social and moral rather than medical for suicide was at 
root a failure of character. Reports of criminal suicides chilled readers by explicating the rationality of attempts to prevent the shame of execution. The injured or dying were represented as essentially sane in seeking to excuse their actions or to repent them, the former a rationalisation, the latter an equally self-possessed act of repentance and reconciliation. Medical men forced to offer an opinion dwelt on the somatic rather than the psychogenic side of 'lunacy' and they emphasized how specific was the link between madness and suicide (Brugis, 1652: 191-206). Rather than accepting the apparently medical verdict of 'lunacy', most professionals knew that coroners inquests were very different from any other tribunal or legal context because: their main constraints were procedural and they were not bound by the same rules of evidence as other courts; they were meant to be participative, which rendered them amenable to influence by family and community. Lawyers, used to substantive common, civil, ecclesiastical, or canon law rather than 'crowner law', stood aghast at their findings. For their part families who would have been happy with an inquest verdict of non compos mentis were unwilling to accept a diagnosis of psychogenic insanity from a doctor, knowing that the two were wholly different things.

It is wrong to state for England that at 'some point during the mid-eighteenth century the men of middling rank who served as coroners' jurors adopted the medical interpretation of suicide' (MacDonald, Murphy, 1990: 114). Indeed, as MacDonald and Murphy themselves point out, medical men almost never supported juries' automatic link between suicide and insanity and nor did any other court. Finding someone non compos mentis on the basis of the act of suicide alone was no more a respectable medical judgement than it was a tenable legal one, for doctors were selective rather than indiscriminate in their association of madness with suicide and few saw any necessary association between suicide and mental ill-health. Lay and professional alike recognised that suicide might be preceded by some form of perturbation of mind arising from transitory unhappiness or suffering that was not necessarily associated with fullblown psychogenic illness. Physicians or surgeons more usually treated madness and suicide as sometimes associated, sometimes separate. Most refused to see any 
necessary link between the wide spectrum of disorders called 'lunacy' or 'insanity' and a propensity to end life, except in the rather specific case of melancholics. Robert Christison knew that the melancholic were more at risk than the manic, carrying on centuries of observation in refusing systematically to link all forms of madness with suicide (Edinburgh University Library Special Collections, Dk4.57, ‘Death from external injuries V: How to distinguish those produced by accident, by the individual himself, or by another': ff. 18v, 20-1; 'Asphyxia III: death by hanging': ff. 49v, 51). Even within this sub-set, doctors knew that not all of those suffering from depressive disorders attempted or committed suicide. When mediating the connection for bereaved relatives doctors had to tread a fine line between what their training told them was credible and what their employers would stomach. Physicians and surgeons in both Scotland and England may sometimes have felt pressured into authenticating a construction placed on death by family and community. In doing so they acted as agents of 'domestic psychiatry' rather than the independent purveyors of medical thought, incorporating rather than replacing lay information in the rendition of medical evidence.

If not during the long eighteenth century, when did a generalised association between madness and suicide become established? Martin Weiner has proposed that 'from the turn of the 1880 s, medical opinion coalesced around a picture of the suicide as a product of mental defect, inherited or acquired' (Weiner, 1990: 266). For Olive Anderson a climate of opinion was 'created by the reasoned belief of so many midVictorian medical men that those who took their own lives were almost invariably suffering from mental disease' (1987: 268). Yet in 1884 a contributor to the Lancet concluded that for most suicides 'it is not their psychical, but their moral condition which is at fault' (In: Jalland, 1996: 71; Anderson, 1987: 242). Even in the 1890s the doctor and barrister Samuel Strahan could conclude his discussion of the link between suicide and insanity by asserting that 'it is tolerably certain that only a small minority of our annual total of suicides arise from madness; that is, from either the absence or the disorder of the mental faculties' (1893: 113). An answer to this question must accept enduring medical, legal and lay attitudes which discriminated between the reasons for 
self-harm and which accepted that suicide could come not from psychogenic or even somatic illness, but from a wrongful personal choice. 


\section{REFERENCES}

Anon. (1750) Rural recreation; or, the employment of a few leisure hours ... also, some thoughts on the sin of self murder. Kendal: T. Ashburner.

Anon. (1759) History of Eugene Aram, who was convicted at York assizes, for the murder of Danl. Clark .... Newcastle: W. \& T. Fordyce.

Anon. (1833) [Report of trials at] Perth [Justiciary] Circuit [Court], Wednesday 17th April 1833. [n.p.].

Adamson DJ (2004) Insanity, idiocy and responsibility: criminal defences in southern Scotland and northern England, c.1660-1830. University of St Andrews, unpublished Ph.D. thesis.

Anderson O (1987) Suicide in Victorian and Edwardian England. Oxford: Oxford University Press.

Andrew DT (1988) The secularization of suicide in England, 1660-1800. Past \& Present 119: 158-65.

Andrew DT (2004) The suicide of Sir Samuel Romilly: apotheosis or outrage. In: Watt (ed.): 174-88.

Bailey V (1998) 'This rash act': suicide across the life cycle in the Victorian city. Stanford: Stanford University Press.

Begbie J (1867-8) On the causes of death in the Scottish Widows' Fund Life Assurance Society. Edinburgh Medical Journal 13: 966-87.

Bentham J (1838) The works of Jeremy Bentham, now first collected; under the superintendence of his executor, John Bowring. 2 vols, Edinburgh: W. Tait.

Berkenkotter C (2008) Patient tales: case histories and the uses of narrative in psychiatry. Columbia: University of South Carolina Press. 
Black W (1789) An arithmetical and medical analysis of the diseases and mortality of the human species. Second edition, London: John Crowder.

Blackstone W (1769) Commentaries of the laws of England. Vol. 4, Oxford: Clarendon Press.

Brugis T (1652) Vade mecum: or, a companion for a chyrurgion ... To which is added the maner of making Reports before a Judge of Assize, of any one that hath come to an untimely end. London: Thomas Williams.

Burney IA (1999) Bodies of evidence : medicine and the politics of the English inquest, 1830-1826. Baltimore, Md.: Johns Hopkins University Press.

Bonfield L (1997) Testamentary cases in the Prerogative Court of Canterbury, 1660-96. In: Brooks CW, Lobban M (eds) Communities and courts in Britain, 1150-1900. London: Hambledon Press, 133-54.

Caradonna, JL (2010) Grub Street and suicide: a view from the literary press in late eighteenth-century France. Journal for Eighteenth-Century Studies 33(1): 23-36.

Cheyne G (1733) The English malady: or a treatise of nervous diseases of all kinds, as spleen, vapours, lowness of spirits, hypochondriacal, and hysterical distempers etc. London: G. Strahan.

Coleborne C (2010) Madness in the family: insanity and institutions in the Australasian colonial world, 1860-1914. Basingstoke: Macmillan.

Collinson GD (1812) A treatise on the laws concerning idiots, lunatics, and other persons non compotes mentis .... Vol. 1, London: Reed.

Davey JG (1870-1) Felo-de-se. The Journal of Mental Science 16: 390-410.

Digby A (1985) Madness, morality and medicine: a study of the York Retreat, 1796-1914. Cambridge: Cambridge University Press.

Eigen JP (1995) Witnessing insanity. Madness and mad-doctors in the English court. New Haven: Yale University Press. 
Gates BT (1988) Victorian suicide: mad crimes and sad histories. Princeton, N.J.:

Princeton University Press.

Gowland A (2006) The worlds of Renaissance melancholy: Robert Burton in context.

Cambridge: Cambridge University Press.

Haakonssen L (1997) Medicine and morals in the Enlightenment: John Gregory, Thomas Percival and Benjamin Rush. Amsterdam: Rodopi.

Hawkins W (1716) A treatise of the pleas of the crown .... Vol. 1. London: Eliz. Nutt.

Healy, R (2006) Suicide in early modern and modern Europe. Historical Journal 49: 903-

19.

Houston RA (1999) 'Not simple boarding': care of the mentally incapacitated in Scotland during the long eighteenth century. In: Bartlett $P$, Wright D (eds) Outside the walls of the asylum: the history of care in the community, 1750-2000. London: Athlone, 19-44.

Houston RA (2000) Madness and society in eighteenth-century Scotland. Oxford: Oxford University Press.

Houston RA (2003a) Legal protection of the mentally incapable in early modern Scotland. Journal of Legal History 24(2): 165-86.

Houston RA (2003b) Rights and wrongs in the confinement of the mentally incapable in eighteenth-century Scotland. Continuity and Change 18(3): 373-94.

Houston RA (2008) The medicalization of suicide: medicine and the law in Scotland and England, c.1750-1850. In: Weaver J, Wright D (eds) A history of suicide in the modern western world: international perspectives. Toronto: University of Toronto Press, 91-118.

Houston RA (2010) Punishing the dead? Suicide, lordship, and community in Britain, 1500-1830. Oxford: Oxford University Press.

Jalland P (1996) Death and the Victorian family. Oxford: Oxford University Press. 
Loudon I (1988) Puerperal insanity in the nineteenth century. Journal of the Royal Society of Medicine 81: 76-79.

MacDonald M (1977) The inner side of wisdom: suicide in early modern England. Psychological Medicine 7 (1977): 565-82.

MacDonald M (1986) The secularization of suicide in England, 1660-1800. Past \& Present. 111: 50-100.

MacDonald M, Murphy TR (1990) Sleepless souls. Suicide in early modern England. Oxford: Oxford University Press.

Melling J, Forsythe W (2006) The politics of madness in England: the state, insanity and society in England, 1845-1914. London: Routledge.

Michael P (2003a) Care and treatment of the mentally ill in north Wales, 1800-2000. Cardiff: University of Wales Press.

Michael P (2003b) From private grief to public testimony: suicides in Wales, 1832-1914. In: Borsay A (ed.) Medicine in Wales, c.1800-2000: public service or private commodity?. Cardiff: University of Wales Press, 40-64.

Moore C (1790) A full inquiry into the subject of suicide. To which are added (as being closely connected with the subject) two treatises on duelling and gaming. Vol.1, London: J. F. and C. Rivington.

Nelson W (1710) The office and authority of a Justice of Peace .... third edition, London: J. Nutt.

Rudolf J (2008) Gender and the development of forensic science: a case study. English Historical Review 123: 924-46.

Shepherd A, Wright D (2002) Madness, suicide and the Victorian asylum: attempted selfmurder in the age of non-restraint. Medical History 46(2): 175-96. 
Siena K (2008) Suicide as an illness strategy in the long eighteenth century. In: Weaver J, Wright $D$ (eds) A history of suicide in the modern western world: international perspectives. Toronto: University of Toronto Press, 53-72.

Siena K (2010) Searchers of the dead in long eighteenth-century London. In: Kippen K, Woods L (eds) Worth and repute: the play of gender in late medieval and early modern Europe. Toronto: Centre for Reformation and Renaissance Studies, 12352.

Snell E (2005) Representations of criminality and victimisation in provincial newspapers: the Kentish Post 1717 to 1768. Southern History 27: 48-75.

Strahan SAK (1893) Suicide and insanity: a physiological and sociological study. London: Swain Sonnenschein \& Co.

Suzuki A (2006) Madness at home: the psychiatrist, the patient, and the family in England, 1820-1860. London: University of California Press.

Watt, JR (2004) Introduction. In: Watt JR (ed.) From sin to insanity: suicide in early modern Europe. Ithaca, NY: Cornell University Press, 1-8.

Weiner M (1990) Reconstructing the criminal: culture, law, and policy in England, 18301914. Cambridge: Cambridge University Press.

Winslow F (1840) The anatomy of suicide. London: Henry Renshaw.

Wright D (1997) Getting out of the asylum: understanding the confinement of the insane in the nineteenth century. Social History of Medicine 10: 137-55.

Weaver J, Wright D (2008) Introduction. In: Weaver J, Wright D (eds) A history of suicide in the modern western world: international perspectives. Toronto: University of Toronto Press, 3-18.

York S (2009) Suicide, lunacy and the asylum in nineteenth-century England. University of Birmingham, unpublished Ph.D. thesis. 


\section{Zelnik RE (1988) From felons to victims: a response to Michael MacDonald.}

Representations 22: 36-59.

1 As Hilary Marland shows in her article, some classes of madness such as insanity of lactation, insanity of pregnancy and, to a lesser extent, puerperal insanity were more closely associated with propensity to suicide in nineteenth-century asylums. See also Loudon, 1988.

2 Criminal forfeiture (including that of felones de se) was abolished in England in 1870.

3 Table based on material presented in Houston, 2010: 32561. The category 'melancholy' includes instances of 'religious melancholy', all from 1808-10. 